\title{
MAPPING SEASCAPES TOURISM DESTINATION IN INDONESIA
}

\author{
Ismayanti Ismayanti \\ Fakultas Ekonomi dan Bisnis, Universitas Sahid \\ Jl. Soepomo No 84, Jakarta Selatan \\ Email Korespondensi:ismayanti_istanto@usahid.ac.id
}

\begin{abstract}
This research was to map prospective seascapes tourism destination. As results, some challenges occurred in seascapes destination development. Thus, it can be concluded that main activities of seascapes tourism are: cruising, yachting, surfing, leisure fishing and watersport activities i.e. Jet skiing. The development of seascapes tourism destination falls into: (1) Pioneering phase takes place in new-found attraction that it is recently built and has potential tourists; (2) Expansion stage occurred in areas that already exist with certain service quality level and loyal customer; (3) Improvement phase, the area is mature and ready-visit; and (4) Revitalization for saturated destination. It was recommended that marine infrastructure and tourist facilities such as: floating pontoons and dinghy-jetty, $F \& B$ establishment and toilet must be constructed. Brand awareness and market penetration are created. Evaluations on existing activities and attractions as well as maintenance of infrastructure, networking and hard-selling act were needed. Sharpen competitive advantages, sustainable marketing strategy; maintain loyalties of tourist, infrastructure and facilities as well as networking are a must. Feature of attraction and activities should be modified, re-adjustment based on tourist's preference and re-orientation on networking when destination reach revitalization phase.
\end{abstract}

Keywords: seascapes, tourism; pioneering;expansion; improvement; revitalization

\begin{abstract}
ABSTRAK
Penelitian ini bertujuan untuk memetakan destinasi wisata bentang laut prospektif. Sebagai hasil, beberapa tantangan terjadi dalam pengembangan destinasi bentang laut. Dengan demikian, dapat disimpulkan bahwa kegiatan utama pariwisata bentang laut adalah: berlayar, berperahu pesiar, berselancar, memancing di waktu luang dan kegiatan olahraga air yaitu ski jet. Pengembangan tujuan wisata bentang laut jatuh ke: (1) Fase perintis terjadi di objek wisata baru yang ditemukan baru-baru ini dibangun dan memiliki potensi wisatawan; (2) Tahap ekspansi terjadi di area yang sudah ada dengan tingkat kualitas layanan tertentu dan pelanggan setia; (3) Fase peningkatan, area matang dan siap dikunjungi; dan (4) Revitalisasi untuk tujuan jenuh. Direkomendasikan bahwa infrastruktur laut dan fasilitas wisata seperti: ponton mengambang dan perahu kecil, pendirian F \& B dan toilet harus dibangun. Kesadaran merek dan penetrasi pasar diciptakan. Evaluasi terhadap aktivitas dan atraksi yang ada serta pemeliharaan infrastruktur, jaringan dan tindakan penjualan keras diperlukan. Mempertajam keunggulan kompetitif, strategi pemasaran yang berkelanjutan; menjaga loyalitas wisatawan, infrastruktur dan fasilitas serta jaringan adalah suatu keharusan. Fitur atraksi dan kegiatan harus dimodifikasi, penyesuaian ulang berdasarkan preferensi wisatawan dan re-orientasi pada jaringan ketika tujuan mencapai fase revitalisasi.
\end{abstract}

Kata kunci: pariwisata, bentang laut; merintis; ekspansi; perbaikan; revitalisasi

\section{INTRODUCTION}


Marine tourism has been play part in tourism industry for years and yachting has become way of life of globa citizen. Yacht industry, from small scale to super yacht, is increasing. As result, land tourism particularly beach area, gain significant benefits. Neighbourhood countries such Malaysia, Singapore, Australia and New Zealand has used the Indonesia's ocean as their playground and give advantages to locals and real positive economic impacts, particularly coastal community.

Located in strategic geographical belt, Indonesia as the biggest archipelagos has 3.000 nauticalmiles seascapes and $95.181 \mathrm{~km}$ seashore, 2nd longest after Canada. Around 78 percent of Indonesia territory is water area and 70 percent of Indonesian live in seashore and small islands, marine life born in their blood. The potentiality of Indonesia's seafaring is huge, however, it only contributed in relatively small numbers, marine tourism only contributed US\$3,5 Billion to total GDP in 2013 (Dahuri, 2014).

For yachters, Indonesia is their concourse that has been sailed through for years, yet befitted to be a tourism destination. It had been their sailing passage, from East to West, from South to North. Individual unorganised visit from yachters is assumed in increasing numbers. Facts showed that the length of stay of yachters in Indonesia water front was 3 months to 6 months. Their spending was around Rp.1, 476 million per person per day. Every boat consisted of up to 5 persons. (Yayasan Cinta Bahari Antar Nusa, 2014). Nevertheless, choices of destinations has not been clearly listed and well-informed to yachter which made them only surpassed Indonesia territory. Database of seascapes tourism destination is definitely needed.

The purpose of research is to map prospective destination to be designated as portfolio of Seascapes tourism. Locus of the research areas are: North Sumatera, Riau Island, DKI Jakarta, Bali, East Nusa Tenggara, Gorontalo, and West Papua. Seven variables operated in observation were (1) environment; (2) attraction; (3) accessibilities derived from connectivity and information; (4) amenities consist of infrastructure and tourism facilities; (5) community participation; (6) tourist behavior, and (7) investment. Focus group discussion with experts, local governments, practitioners, association and media were also conducted.

\section{METHODOLOGY}

Mapping seascape destinasion was started from the point that where every seascape destination needs orientation and promotion of the touristic objectives with a uniform character which allow the creation of specialised touristic products as well as of certain touristic connection efficients from the economic point of views. Taking into account this goal the methods of grouping these localities regarding type of development and category of seascape destination, facilities and services as well as attraction within 2-hours driving. The main instrument used in order to demarcate the seascape destination is represented by the spatial geographical mapping with references of RIPPARNAS (Rencana Induk Pengembangan Pariwisata Nasional) 2016-2025 which mentioned the spatial delination of each destination, area and sites. In order to achieve the delimitation of the seaspace destination, it is created a cluster mapping by observation with instrument of check list.

\section{RESULT AND DISCUSSION}


Government has targeted 4 million international visitor contribution of marine tourism in 2019 and seascapess tourism provide 25 percent of it or 500.000 visitors with 6.000 yachts. With increasing number of yachts thus seascapes tourism destination is definetely developed with all acessibility, facilities and services.

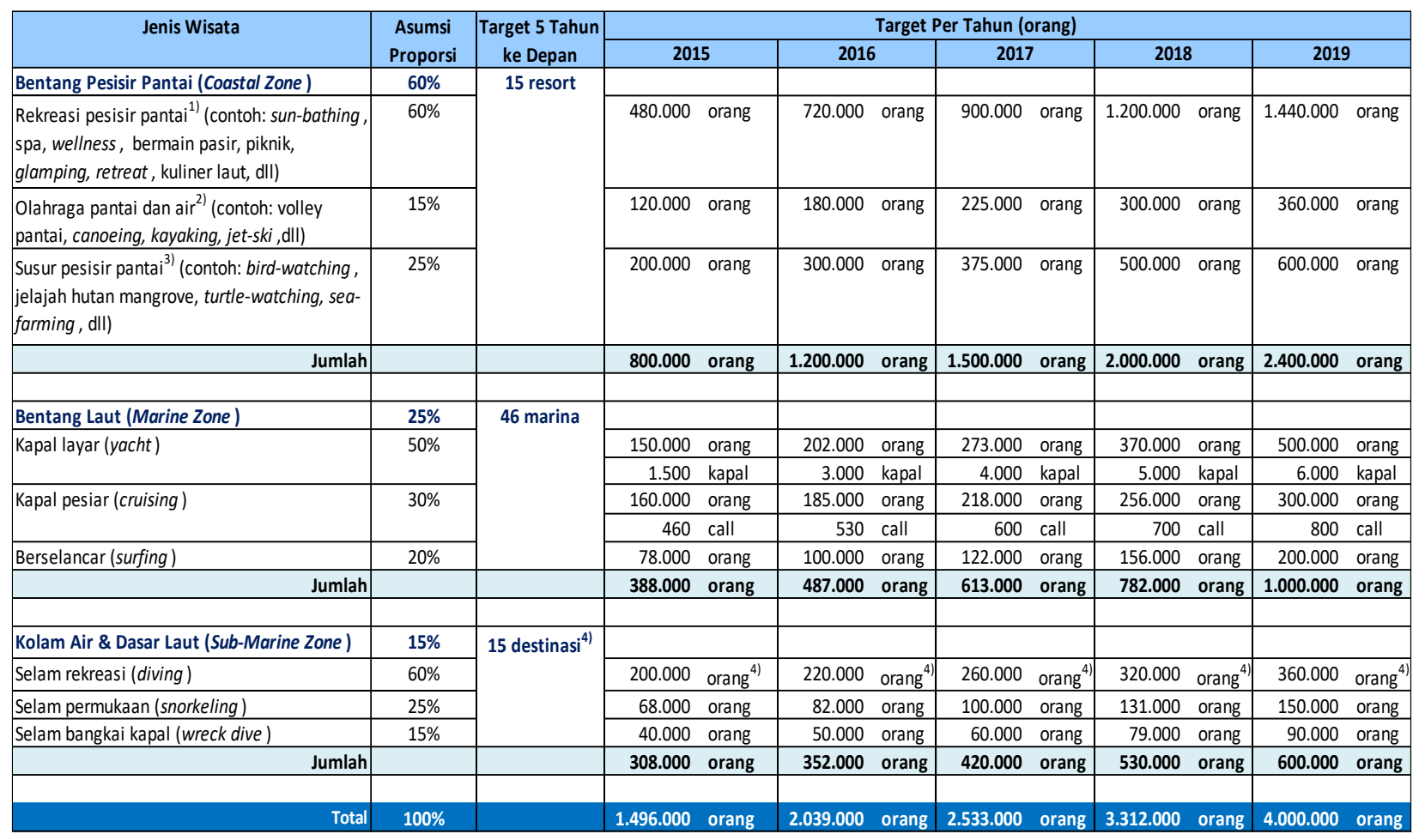

Keterangan:

1) Rekreasi pesisir pantai adalah kegiatan rekreasi yang dilakukan di pesisir pantai, seperti: bermain pasir, bermain layang-layang, memancing, menyusun pasir, koleksi cangkang kerang, mandi matahari, piknik, barbekyu, banana boating, dll.

2) Olahraga pantai dan air adalah kegiatan olahraga yang dilakukan di pesisir pantai dan perairan pesisir, contoh olahraga pantai: Volley pantai, berkuda, jogging, surfing pasir, seluncur pantai, dll. Contoh olahraga air: polo air, kayaking, kanoeing, jet ski, dll.

3) Susur pantai adalah kegiatan jelajah dan pengamatan ekosistem di pesisir pantai, contoh: padang lamun, penanaman rumput laut, mangrove trail, bird-watching, turtle-watching, sea4) Data diambil dari Rencana Aksi Bidang Bawah Laut (Cipto Aji, 2015)

Figure 3. Projection of Yacht Tourism Year 2019 (Source: Kemenpar, 2015)

Yachties is term used to call yachtsman or sailing enthusiast, they are visitors or tourists conducting their journey over the sea and visit seascapes tourism destination along the way (sail passage). They are a well-prepared tourist, starting from planning the routes until proving the supplies. Yachties are premium tourist, demand high quality products and excellent services. Their spending power are high since they come from middle to high class society. They also give direct contribution to local whenever they are anchored or moored or berthed in a seascapes tourism destination. Average spending of yachties in Indonesia are Rp. 1,5 million per person per day and their length of stays are 3 month to 6 months.

Well-preparation and detailed itinerary is a must eventhough flexibility along the trip may change their plan. They have route's plan from country to country, from destination to destination and they are travel in a group.

When yachties visited Indonesia, they must enter and exit thru 18 appointed gate to process the clearance to enter Indonesia territory. New Indonesia CIQP procesedure had applied with online system (New Yacht Electronic Registration system name Yachters 
Indonesia). Yachties may also do inward clearance guided by yacht operators. Certain port such as Kupang, Tual, Bitung, Tarakan and Batam are highly recommended.

Popular travel pattern of yacthies is: starting from Kupang, Alor, Flores, Labuan Bajo, Sumbawa, Lombok, Kumai, Belitung and ended in Batam. Some are also transit in Karimun Jawa. Information about sailing routes are provided by yacht operators. The information includes the sail passage, seascapes destination and facilities-serviced available.

Most of yachties comes from: Australia, United State, European countries, Japan, Malaysia and Singapore. They are advonturer, mature age, more than 45 years and lots of them are pensioners. Some solo yachties are men, some yachties sail with friends, families and relatives. They are independent, free sail but highly dangle with yacht operator for easeness and services particularly CIQP services. They are all very keen with culture especially marine life and local coastal community.

\section{MAPPING SEASCAPES DESTINATION IN INDONESIA}

There are challenges in developing seascapes tourism destination in Indonesia. Those are: (1) medium to high risk marine environment; (2) low ease of access to and within destination, particularly to East part of Indonesia; (3) rarity of readiness and variety of tourist attraction lead to unattractive tour packages; (4) poor infrastructure and low maintenance of tourist facilities; (5) inadequate and incompetence of manpower in destination; (6) immature behavior of tourist toward sustainability, and (7) lack of local government support in financial issues. Yachties in Indonesia demand necessities in seascapes tourism destination as follows:

1. Safety

Sea piracy in Indonesia territory is hardly occurred but stealing and criminal activities are happened especially when yachties stopover in seascape tourism destination in Indoensia. Thus, neighbourhood watch concept is recommended when yachties sail in groups.

2. Languange

Most yacthies are foreigner and English is a must, although they are willing to learn simple Bahasa Indonesia for daily conversation. They wish local community eager to learn English as international languange for communication.

3. Money

Seascapes destination is likely located in coastline, far from crowd and local people depend on cash transaction. Credit card and debit card is expectly used when visit a destination since traveller cheques is uncommon in Indonesia. The withdrawn limitation of Rp. 2,5 million in ATM is a problem along with maximum twice withdrawn with $\$ 7$ fee per transaction.

4. Yacht sparepart

It is very difficult to find yacht sparepart particularly when sailing to Eastern part of Indonesia. The price of spare part is expensive as import tax in Indonesia is high. Most demand spare part from yachties are fuel filter.

5. Weapon regulation

Indonesia is restrict with weapon and ammunition regulation. All armory should be registered and sertified by origin country and reported to authority in Indonesia since the 
regulation stated that whoever brings unlicence armament into Indonesia territory will be jailed and fined.

6. Pet on board

Yacht is like home, they design the boat as homely as possible. Some of yachties bring pet ie. Dogs, Cats and other. There is strict regulation about pets in Indonesia and quarantine authority demand health documents and vaccine certificate of yachties' pet.

7. Market

Whilst visiting destination, yachties seek supply for their yachts. Food stock is the issues since the food required are unavailable in local market in Indonesia. Yachties favorable food stock are: fresh fish, fruit and veggies, wines, cheese, meat and olive oil.

8. Internet

Indonesia has been connected with internet but the connection is slow and unstable. When arriving in destination, internet for communication is needed by yachties. They may contact the family or relative or even business partners using land line.

9. Medical service

Medical service in destination has not yet internationalised and most yacthies prefers oncall doctor which should be provided by yacht operators.

10. Bargaining

Yachties are middle-to-high class people but still they enjoy bargaining for experience. They enjoy the process of negotiation, however, they will be furious whenever local people try to cheat.

11. Clean and fresh water

Clean and fresh water is common need for yachties, however, it is also common problem in Indonesia. Coastal area has brackish water which salty and undrinkable. Thus, it is important to provide clean and fresh water for them.

12. Fuel

Price of fuel in Indonesia is unstable and considered 'cheap', however the fuel is not always available all the time. Fuel in seascapess destination is sometime scarces. Apart from fuel, yachties need gas provided by Pertamina as Indonesia has regulation that it is unallow to refuel non-Indonesia gas tube, thus they should buy Indonesian gas tube whenever entering Indonesia ocean.

Based on identified desires and feature of seascapes above, it can be seen the recap of seascapes tourism destination: 


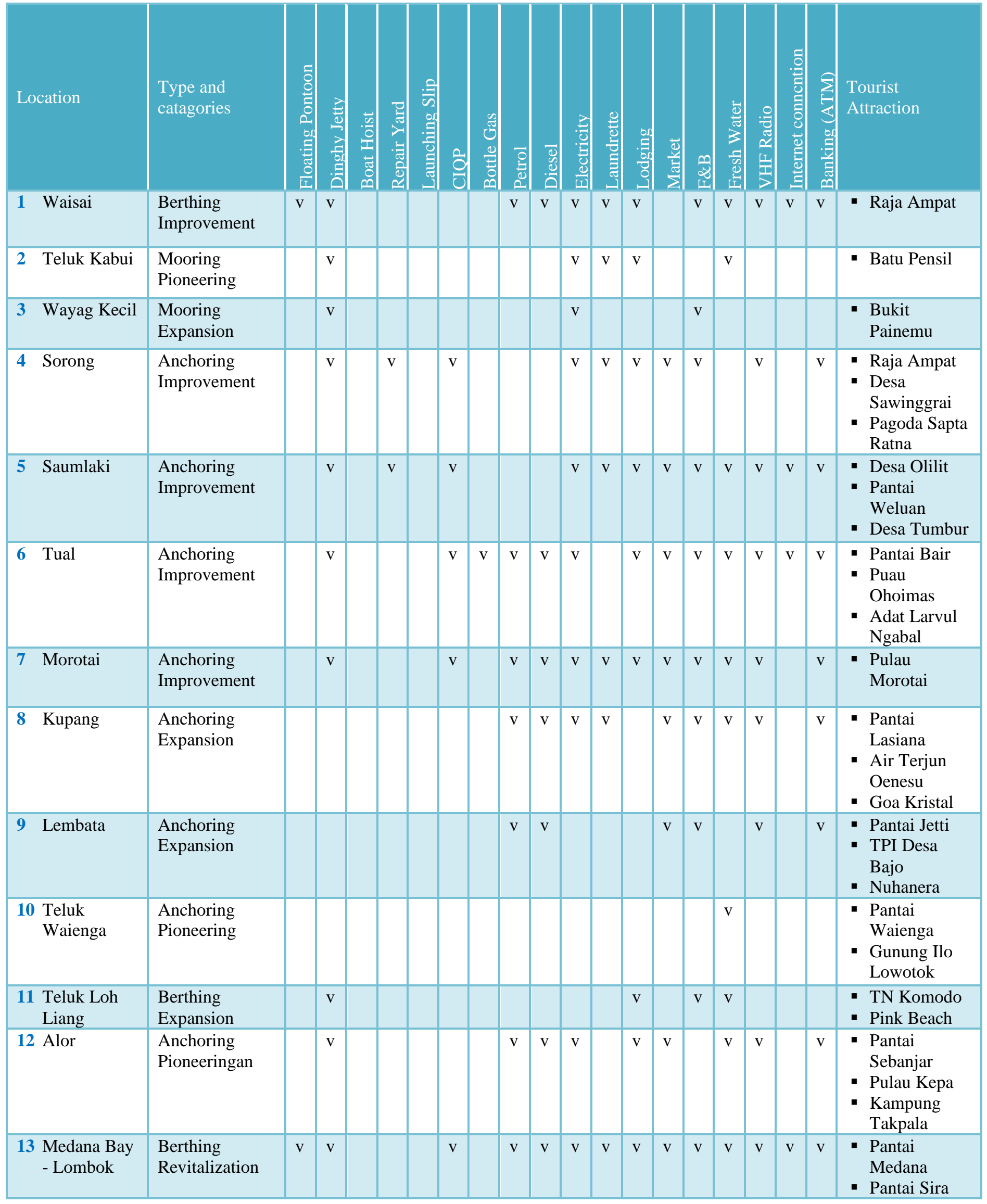


Vol 1, No. 1, 2018

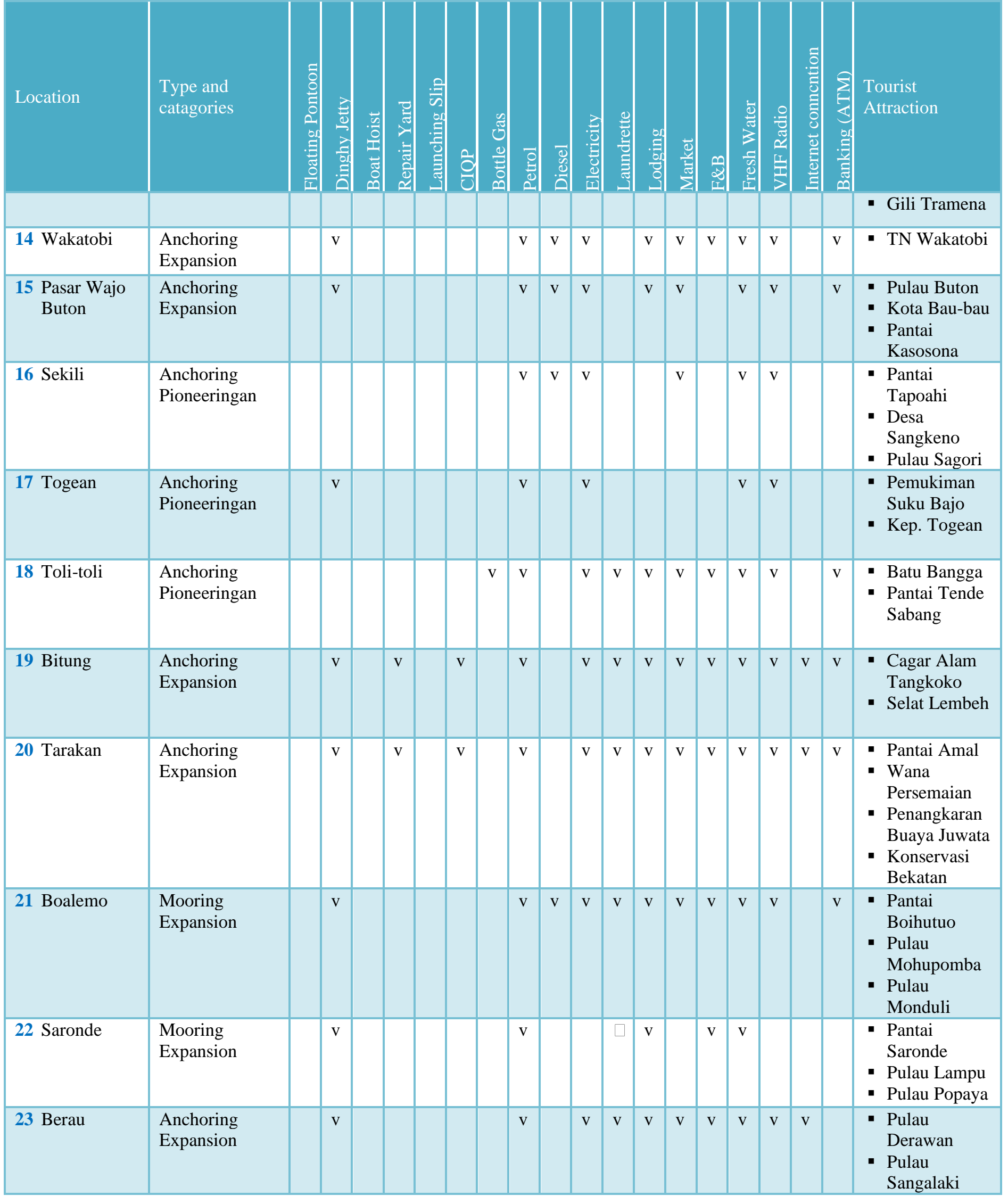


Vol 1, No. 1, 2018

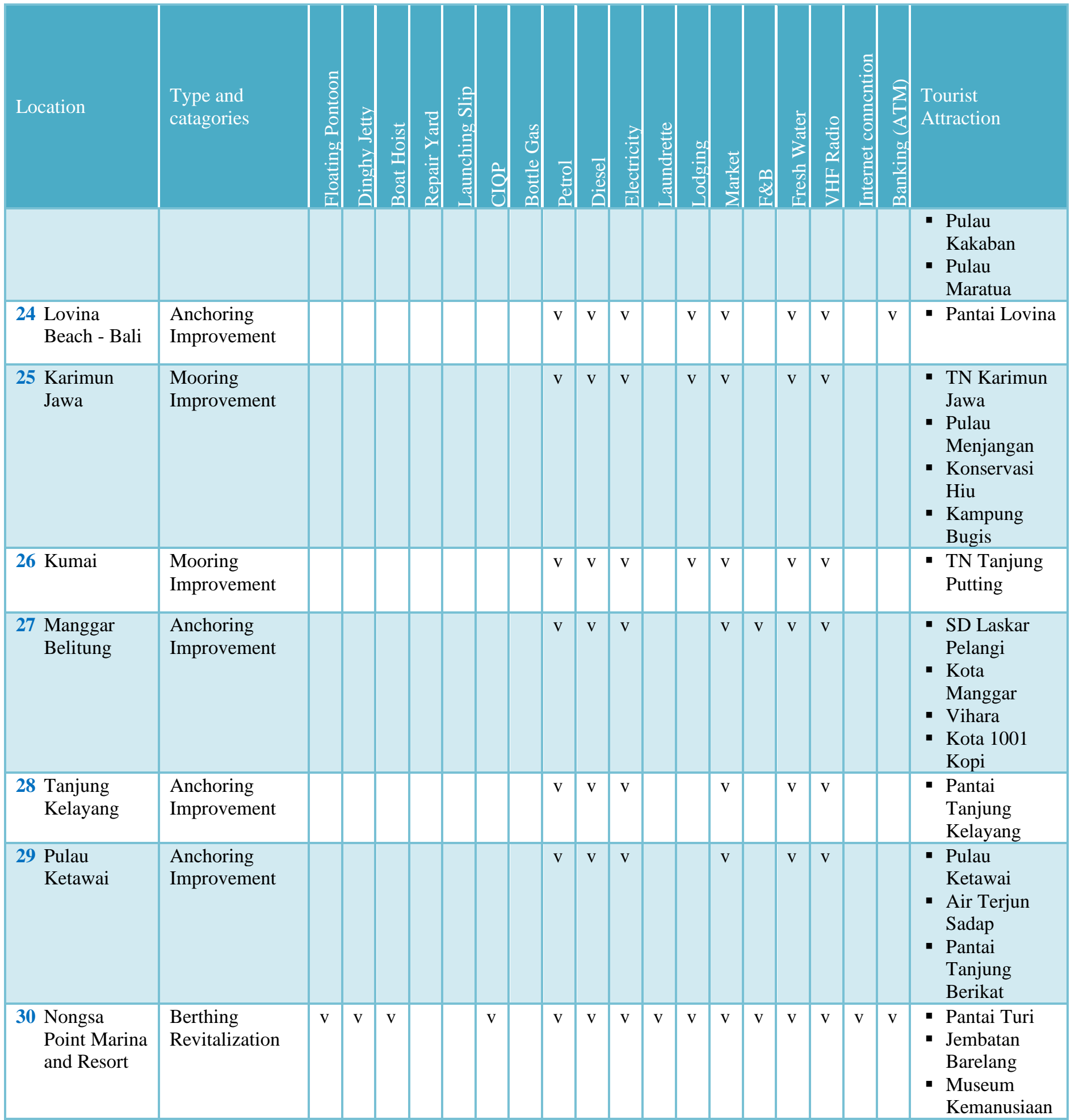




\section{CONCLUSION}

After mapping, it can be concluded that main activities of seascapes tourism are: cruising, yachting, surfing, leisure fishing and watersport activities i.e. Jet skiing. The development of seascapes tourism destination falls into four stage: (1) pioneering, (2) expansion, (3) improvement, and (4) revitalization. Pioneering phase takes place in newfound attraction that it is recently built and has potential tourists. Expansion stage occurred in areas that already exist with certain service quality level and loyal customer. The destination has variety of activities and attraction. In improvement phase, the area is mature and ready-visit. Last stage is revitalization. The seascapes destination is saturated, thus, differentiation on every aspect is definitely required for continuum destination.

It is recommended that in pioneering phase, marine infrastructure and tourist facilities such as: floating pontoons and dinghy-jetty, F\&B establishment and toilet must be constructed. Brand awareness and market penetration are created. Evaluations on existing activities and attractions as well as maintenance of infrastructure, networking and hard-selling act were needed in expansion phase. Whilst in improvement stage, sharpen competitive advantages, sustainable marketing strategy; maintain loyalties of tourist, infrastructure and facilities as well as networking are a must. Finally, feature of attraction and activities should be modified, re-adjustment based on tourist's preference and re-orientation on networking when destination reach revitalization phase.

\section{REFERENCES}

Atkinson, S. Et.Al. (2009). The SEaschapes Guidebook: How to Select, Develop and Implement Seascapess, Arlington: Conservation International.

Dahuri, R. (2014). Pariwisata Bahari: Raksasa Ekonomi Indonesia yang Masih Tidur, Jakarta: Tabloid Maritim.

Director General of Sea Transpotation Policy number HK.103/4/8/DJPL.15 about Service Procedure of Sailing Permit for Yacht in Indonesia Territory.

Isik, D.A, Cerit, A,G. (2008). Yacht Tourism Ecucation: a Stuy on Curriculums, IMLA 2008 Proceeding, Izmir, Turkey: Dokuz Eylul University.

Mann, R. (1992). Marine Tourism Indonesia, Gateway Books.

McKenna, Allen, Suryadi (2002). A Marine Rapid Assessment of the Raja Ampat Islands, Papua Province, Indonesia, Washington: Conservation International.

Ministry of Finance Policy number 261/PMK.04/2015 tahun 2015 about Import of Yachts.

Ministry of Transportation Policy number PM 171 year 2015 about Service Procedure of Foreign Yachths to Indonesia Territory.

Presidential Decree number 105 year 2015 about Visitation of Foreign Yacht to Indonesia. 
Vol 1, No. 1, 2018

Sariisik, M., Turkay, O., Akova, O. (2011). How to manage yacht tourism in Turkey: a SWOT analysis and related strategies. Procedia Social and Behaviour Sciences., 24 (2011) pp.1014-1025.

Tourism Act number 10 year 2009 about Tourism.

Transportation Act number 17 year 2008 about Sailing. 